\title{
Arsenic contamination in surface and groundwater in major parts of Manikganj district, Bangladesh
}

\author{
Atia Akter, M. Y. Mia and H. M. Zakir ${ }^{1^{*}}$ \\ Department of Environmental Science and Resource Management, Mawlana Bhashani Science and Technology \\ University, Tangail-1902, Bangladesh and ${ }^{1}$ Department of Agricultural Chemistry, Bangladesh Agricultural University, \\ Mymensingh-2202, Bangladesh, *E-mail: zakirhm.ac.bau@gmail.com
}

\begin{abstract}
The contamination of groundwater by arsenic (As) in Bangladesh is the largest poisoning of population in history, with millions of people exposed. Thirty (30) water samples were collected from 5 different Upazilas of Manikganj district in Bangladesh to determine the concentration of As as well as to assess the level of contamination. Concentrations of As in waters were within the range of 0.27 to 1.96 ; 0.43 to 5.09 ; trace to $6.69 \mathrm{mg} \mathrm{L}^{-1}$ at Singair, Harirampur and Ghior Upazila, respectively. But the concentration of As in waters both of Manikganj sadar and Shivalaya Upazila were trace. All surface and groundwater samples of Singair and Harirampur, and 4 groundwater samples of Ghior Upazila's exceeded Bangladesh standard value for As concentration $\left(0.05 \mathrm{mgL}^{-1}\right)$. The highest As concentration (6.69 $\left.\mathrm{mgL}^{-1}\right)$ was found in groundwater of Baliakhora village of Ghior upazila in Manikganj district. The cation chemistry indicated that among 30 water samples, 15 showed dominance sequence as $\mathrm{Mg}^{2+}>\mathrm{Ca}^{2+}>\mathrm{Na}^{+}>\mathrm{K}^{+}$and 14 samples as $\mathrm{Ca}^{2+}>\mathrm{Mg}^{2+}>\mathrm{Na}^{+}>\mathrm{K}^{+}$. On the other hand, the dominant anion in water samples was $\mathrm{Cl}^{-}$followed by $\mathrm{HCO}_{3}{ }^{-}$and $\mathrm{SO}_{4}{ }^{2-}$. Highly significant positive correlations were found in between the concentrations of $\mathrm{As}^{2}$ and $\mathrm{SO}_{4}{ }^{2-}$ $\left(r=712^{\star \star}\right)$, and $\mathrm{As}$ and $\mathrm{Ca}^{2+}\left(r=581^{*}\right)$, suggesting similar sources and/or similar geochemical processes controlling the occurrence of these ions in waters.
\end{abstract}

Keywords: Arsenic pollution, Water, Manikganj, Bangladesh

\section{Introduction}

Arsenic is a metalloid which is widely distributed in the environment. It is recognized as one of the world's greatest environmental hazards, threatening the lives of several hundred million people. However, in terms of population exposure the most severe case of such contamination is observed in Bangladesh where it is considered to be the largest mass poisoning in history. Evidences of high soil and plant arsenic levels have been found due to the introduction of arsenic-contaminated water in crop fields. Again, there is a possibility of using the contaminated water for cooking. As a result, even more people are exposed to toxic level of As through food chain (Imtiaz et al., 2009).

Data collected from different governmental bodies, NGOs and private organizations reveal that a large number of populations in Bangladesh are suffering from melanosis, leuco-melanosis, keratosis, hyperkeratosis, dorsum, non-petting oedema, gangrene and skin cancer (Karim, 2000). The occurrence of arsenic diseases depends on the ingestion of arsenic compounds and their excretion rate from the body. It has been reported that $40-60 \%$ arsenic can be retained by the human body after ingestion (Farmer and Johnson, 1990). Due to the widespread use of As contaminated ground water in drinking, cooking, agriculture, etc. As can reach to human body from many possible routes, by which the daily dietary intake of As may exceeds the WHO recommended limit $\left(2.14 \mu \mathrm{g} \mathrm{kg}^{-1}\right.$ of the body mass) (Imtiaz et al., 2009).

Manikganj is one among the As contaminated districts of Bangladesh and thousands of peoples are affected over there by As contamination. Groundwater is the main source of As contamination in this district. If such condition prevails for long time peoples of that area will be affected seriously by arsenicosis. Considering the above facts, the research work has been carried out to determine the concentration of As and to assess the level of contamination in waters collected from five (5) different Upazilas of Manikganj district of Bangladesh. 


\section{Materials and Methods}

A total of 30 water samples were collected from 30 locations of 5 different Upazila's of Manikganj district during the month of February, 2013 following the sampling techniques as outline by APHA (1995) and Sincero and Sincero (2004) (Table 1). The water samples were taken in $500 \mathrm{~mL}$ plastic bottles, which were cleaned in the laboratory with dilute $\mathrm{HCl}(1: 1)$ and then rinsed twice with distilled water. Before sampling, bottles were also rinsed with the sampled water. The bottles containing water samples were sealed immediately to avoid exposure to air and marked with necessary information.

In the laboratory, the water samples were filtered through Whatman no. 42 filter paper to separate undesirable solid and suspended materials. Then the samples were analyzed for $\mathrm{pH}$, electrical conductivity (EC), total dissolved solids (TDS), dissolved oxygen (DO), major cations $\left(\mathrm{Ca}^{2+}, \mathrm{Mg}^{2+}, \mathrm{Na}^{+}\right.$ and $\left.\mathrm{K}^{+}\right)$and major anions $\left(\mathrm{Cl}^{-}, \mathrm{CO}_{3}{ }^{2-}, \mathrm{HCO}_{3}^{-}, \mathrm{SO}_{4}{ }^{2-}\right.$ and $\mathrm{PO}_{4}{ }^{3-}$ ) at the laboratories of the Department of Environmental Science and Resource Management, Mawlana Bhashani Science and Technology University, Tangail-1902 and the Department of Agricultural Chemistry, Bangladesh Agricultural University, Mymensingh-2202. Calcium and magnesium were determined titrimetrically using standard $\mathrm{Na}_{2}$ EDTA (Ghosh et al., 1983; Page et al., 1989). Chloride was measured by titrimetrically using standard $\mathrm{AgNO}_{3}$ solution. Carbonate and bicarbonate were also determined by titrimetrically using standard $\mathrm{H}_{2} \mathrm{SO}_{4}$ solution (Ghosh et al., 1983; Singh et al., 1999). Sodium and potassium were measured by flame photometrically whereas sulphate and phosphate were determined by spectrophotometrically (Ghosh et al., 1983; Tandon, 1995; Singh et al., 1999). The concentration of arsenic in water samples were analyzed by atomic absorption spectrophotometer by using the single element hallow cathode lamp at the wavelength of $193 \mathrm{~nm}$ following the procedure as described by APHA (1995).

Table 1. Detailed information regarding water sampling sites of Manikganj district, Bangladesh

\begin{tabular}{|c|c|c|c|}
\hline Sample ID & Source of water & Name of village & Name of upazila \\
\hline 01 & Tubewell & Charigram & Singair \\
\hline 02 & Tubewell & Talibpur & Singair \\
\hline 03 & Tubewell & Singair & Singair \\
\hline 04 & Tubewell & Jamsha & Singair \\
\hline 05 & Pond & Joy Mantop & Singair \\
\hline 06 & Pond & Jamirta & Singair \\
\hline 07 & Tubewell & Saista & Singair \\
\hline 08 & Tubewell & Balla & Harirampur \\
\hline 09 & Pond & Gala & Harirampur \\
\hline 10 & Tubewell & Chala & Harirampur \\
\hline 11 & Tubewell & Balara & Harirampur \\
\hline 12 & Tubewell & Harukandi & Harirampur \\
\hline 13 & Tubewell & Ramkrishnapur & Harirampur \\
\hline 14 & Tubewell & Boyra & Harirampur \\
\hline 15 & Tubewell & Kalta Hat & Ghior \\
\hline 16 & Tubewell & Nali & Ghior \\
\hline 17 & Tubewell & Baniajuri & Ghior \\
\hline 18 & Tubewell & Baliakhora & Ghior \\
\hline 19 & Tubewell & Ashapur & Ghior \\
\hline 20 & Tubewell & Singjuri & Ghior \\
\hline 21 & Tubewell & Baratia & Ghior \\
\hline 22 & Tubewell & Krishnapur & Manikganj Sadar \\
\hline 23 & Tubewell & Betila Mitra & Manikganj Sadar \\
\hline 24 & Pond & Nabagram & Manikganj Sadar \\
\hline 25 & Pond & Putail & Manikganj Sadar \\
\hline 26 & Tubewell & Balirtek & Manikganj Sadar \\
\hline 27 & Tubewell & Uthali & Shivalaya \\
\hline 28 & Tubewell & Mahadebpur & Shivalaya \\
\hline 29 & Tubewell & Ulail & Shivalaya \\
\hline 30 & Tubewell & Arua & Shivalaya \\
\hline
\end{tabular}




\section{Results and Discussion}

The results of the analysis of water samples collected from 5 different Upazila's of Manikganj district, Bangladesh is given in Tables 2 (a-e) and in Figs. 1 (a-c).

\section{Physicochemical properties of water}

The $\mathrm{pH}$ of water samples collected from 5 different Upazila's of Manikganj district were slightly alkaline in nature (7.04 to 7.99) and data are presented in Tables 2(a-e). These might be due to the dominance of ions such as $\mathrm{Ca}^{2+}, \mathrm{Mg}^{2+}$ and $\mathrm{Na}^{+}$in water (Rao et al., 1982). The acceptable range of $\mathrm{pH}$ for drinking water is 6.5 to 8.5 ; recreational water is 6.0 to 9.5 ; industrial water is 6.0 to 9.5 ; livestock water is 5.5 to 9.0 (ADB, 1994). On the basis of measured $\mathrm{pH}$ most of the samples were within the acceptable range.

Electrical conductivity $(E C)$ represents the total concentration of soluble salts in water. The EC of all collected water samples from different Upazila's of Manikganj district were within the range of 27 to 82 $\mu \mathrm{Scm}^{-1}$ (Tables 2a-e). The acceptable range of EC for recreational water is $500 \mu \mathrm{S} \mathrm{m}^{-1}$, irrigation water is $750 \mu \mathrm{S} \mathrm{cm} \mathrm{cm}^{-1}$ and fishing water is 800 to $1000 \mu \mathrm{S} \mathrm{cm}^{-1}$ (ADB, 1994). And the measured EC of all samples collected from different Upazila's of Manikganj district were below the acceptable range. The DO of all water samples varied from 3.2 to $8.0 \mathrm{mgL}^{-1}$ (Tables 2a-e). According to the United States Public Health (USPH) and Indian Standard Institution (ISI), the acceptable range of DO for domestic water supplies is 4.0 to $6.0 \mathrm{mgL}^{-1}$ and $3.0 \mathrm{mgL}^{-1}$, respectively (De, 2005). The acceptable range of DO for fish culture is from $5 \mathrm{mgL}^{-1}$ to saturation (Meade, 1998) and more than $5.00 \mathrm{mgL}^{-1}$ (Chowdhury, 2007). TDS values of water samples collected from different Upazila's of Manikganj district were within the range of 173 to $529 \mathrm{mgL}^{-1}$ (Tables 2a-e). The acceptable standards of TDS for drinking water is $1000 \mathrm{mg} \mathrm{L}^{-1}$, industrial water is $1500 \mathrm{mg} \mathrm{L}^{-1}$, livestock water is $5000 \mathrm{mg} \mathrm{L}^{-1}$ and irrigation water is $2000 \mathrm{mg} \mathrm{L}^{-1}$ (ADB, 1994). On the basis of measured TDS all samples collected from Manikganj district were within the acceptable range.

Table 2a. Physicochemical properties of water samples collected from Singair Upazila of Manikganj district, Bangladesh

\begin{tabular}{|c|c|c|c|c|c|c|c|c|c|c|c|c|}
\hline $\begin{array}{c}\text { Sample } \\
\text { ID }\end{array}$ & $\mathrm{pH}$ & $\begin{array}{c}\text { EC } \\
\mu \mathrm{Scm}^{-1}\end{array}$ & $\begin{array}{c}\mathrm{DO} \\
\mathrm{mgL}^{-1}\end{array}$ & $\begin{array}{l}\text { TDS } \\
\mathrm{mgL}^{-1}\end{array}$ & $\begin{array}{c}\mathrm{Cl}^{-} \\
\mathrm{mgL}^{-1}\end{array}$ & $\begin{array}{l}\mathrm{HCO}_{3}^{-} \\
\mathrm{meL}^{-1}\end{array}$ & $\begin{array}{l}\mathrm{PO}_{4}{ }^{3-} \\
\mathrm{mgL}^{-1}\end{array}$ & $\begin{array}{l}\mathrm{SO}_{4}{ }^{2-} \\
\mathrm{mgL}^{-1}\end{array}$ & $\begin{array}{l}\mathrm{Ca}^{2+} \\
\mathrm{mgL}^{-1}\end{array}$ & $\begin{array}{l}\mathrm{Mg}^{2+} \\
\mathrm{mgL}^{-1}\end{array}$ & $\begin{array}{c}\mathrm{Na}^{+} \\
\mathrm{mgL}^{-1}\end{array}$ & $\begin{array}{c}\mathrm{K}^{+} \\
\mathrm{mgL}^{-1}\end{array}$ \\
\hline 1 & 7.32 & 66 & 5.5 & 420 & 49.98 & 9.0 & 0.50 & nd & 76.95 & 94.77 & 38.59 & 13.33 \\
\hline 2 & 7.70 & 46 & 3.2 & 273 & 19.99 & 5.0 & 0.56 & nd & 67.33 & 63.18 & 34.07 & 12.52 \\
\hline 3 & 7.62 & 66 & 4.0 & 423 & 54.98 & 10.0 & 0.60 & 2.42 & 89.78 & 36.73 & 44.12 & 14.54 \\
\hline 4 & 7.29 & 64 & 7.0 & 401 & 49.98 & 9.0 & 0.73 & 2.97 & 126.65 & 94.77 & 32.56 & 12.11 \\
\hline 5 & 7.39 & 80 & 3.2 & 513 & 179.94 & 9.0 & 0.08 & 0.48 & 40.08 & 63.18 & 25.03 & 26.69 \\
\hline 6 & 7.36 & 81 & 6.5 & 510 & 144.96 & 7.0 & 0.50 & 2.59 & 25.65 & 260.01 & 25.03 & 26.69 \\
\hline 7 & 7.62 & 50 & 5.5 & 317 & 49.98 & 6.0 & 0.95 & 1.50 & 76.95 & 68.04 & 32.56 & 12.52 \\
\hline Max. & 7.7 & 81 & 7.0 & 513 & 179.94 & 10.0 & 0.95 & 2.97 & 126.65 & 260.01 & 44.12 & 26.69 \\
\hline Min. & 7.29 & 46 & 3.2 & 273 & 19.99 & 5.0 & 0.08 & 0.48 & 25.65 & 36.73 & 25.03 & 12.11 \\
\hline Mean & 7.47 & 64.71 & 4.99 & 408.1 & 78.54 & 7.86 & 0.56 & 1.99 & 71.91 & 97.24 & 33.14 & 16.91 \\
\hline SD & 0.17 & 13.35 & 1.54 & 89.77 & 59.33 & 1.86 & 0.26 & 1.01 & 33.02 & 74.54 & 6.87 & 6.72 \\
\hline
\end{tabular}

nd= not detectable

Table 2b. Physicochemical properties of water samples collected from Harirampur Upazila of Manikganj district, Bangladesh

\begin{tabular}{|c|c|c|c|c|c|c|c|c|c|c|c|c|}
\hline Sample ID & $\mathrm{pH}$ & $\begin{array}{c}\text { EC } \\
\mu \mathrm{Scm}^{-1}\end{array}$ & $\begin{array}{c}\mathrm{DO} \\
\mathrm{mgL}^{-1}\end{array}$ & $\begin{array}{c}\text { TDS } \\
\mathrm{mgL}^{-1}\end{array}$ & $\begin{array}{c}\mathrm{Cl}^{-} \\
\mathrm{mgL}^{-1}\end{array}$ & $\begin{array}{l}\mathrm{HCO}_{3}^{-} \\
\mathrm{meL}^{-1}\end{array}$ & $\begin{array}{l}\mathrm{PO}_{4}{ }^{-3} \\
\mathrm{mgL}^{-1}\end{array}$ & $\begin{array}{l}\mathrm{SO}_{4}{ }^{2-} \\
\mathrm{mgL}^{-1}\end{array}$ & $\begin{array}{c}\mathrm{Ca}^{2+} \\
\mathrm{mgL}^{-1}\end{array}$ & $\begin{array}{l}\mathrm{Mg}^{2+} \\
\mathrm{mgL}^{-1}\end{array}$ & $\begin{array}{c}\mathrm{Na}^{+} \\
\mathrm{mgL}^{-1}\end{array}$ & $\begin{array}{c}\mathrm{K}^{+} \\
\mathrm{mgL}^{-1}\end{array}$ \\
\hline 8 & 7.20 & 61 & 5.0 & 375 & 39.99 & 7.0 & 0.47 & 0.09 & 105.81 & 77.76 & 33.07 & 13.33 \\
\hline 9 & 7.62 & 50 & 3.5 & 309 & 44.97 & 5.0 & 0.19 & 1.82 & 70.54 & 72.9 & 37.09 & 18.59 \\
\hline 10 & 7.04 & 68 & 3.4 & 421 & 24.99 & 6.0 & 1.69 & 0.69 & 107.41 & 89.91 & 35.58 & 13.33 \\
\hline 11 & 7.99 & 60 & 6.6 & 380 & 49.98 & 8.0 & 0.18 & 11.00 & 121.84 & 65.61 & 30.05 & 13.33 \\
\hline 12 & 7.40 & 28 & 4.4 & 174 & 39.99 & 6.0 & 0.48 & nd & 64.13 & 172.53 & 25.53 & 12.52 \\
\hline 13 & 7.36 & 28 & 5.2 & 178 & 29.99 & 8.0 & 0.23 & 0.06 & 56.11 & 133.65 & 25.53 & 12.52 \\
\hline 14 & 7.36 & 29 & 5.5 & 186 & 49.98 & 9.0 & 0.10 & 0.31 & 52.91 & 233.28 & 26.03 & 12.52 \\
\hline Max. & 7.99 & 68 & 6.6 & 421 & 49.98 & 9.0 & 1.69 & 11.00 & 121.84 & 233.28 & 37.09 & 18.59 \\
\hline Min. & 7.04 & 28 & 3.4 & 174 & 24.99 & 5.0 & 0.1 & 0.06 & 52.91 & 65.61 & 25.53 & 12.52 \\
\hline Mean & 7.42 & 46.29 & 4.8 & 289 & 39.98 & 7.0 & 0.48 & 2.39 & 82.68 & 120.81 & 30.41 & 13.73 \\
\hline SD & 0.31 & 17.59 & 1.14 & 107.7 & 9.57 & 1.41 & 0.55 & 4.29 & 28.18 & 62.77 & 4.92 & 2.18 \\
\hline
\end{tabular}

nd $=$ not detectable 
Table 2c. Physicochemical properties of water samples collected from Ghior Upazila of Manikganj district, Bangladesh

\begin{tabular}{|c|c|c|c|c|c|c|c|c|c|c|c|c|}
\hline Sample ID & $\mathrm{pH}$ & $\begin{array}{c}\mathrm{EC} \\
\mu \mathrm{Scm}^{-1}\end{array}$ & $\begin{array}{c}\mathrm{DO} \\
\mathrm{mgL}^{-1}\end{array}$ & $\begin{array}{c}\mathrm{TDS}_{\mathrm{mgL}}^{-1} \\
\mathrm{mgl}^{-1}\end{array}$ & $\begin{array}{c}\mathrm{Cl}^{-} \\
\mathrm{mgL}^{-1}\end{array}$ & $\begin{array}{c}\mathrm{HCO}^{-} \\
\mathrm{meL}^{-1}\end{array}$ & $\begin{array}{c}\mathrm{PO}_{4}^{3-} \\
\mathrm{mgL}^{-1}\end{array}$ & $\begin{array}{c}\mathrm{SO}_{4}^{2-} \\
\mathrm{mgL}^{-1}\end{array}$ & $\begin{array}{c}\mathrm{Ca}^{2+} \\
\mathrm{mgL}^{-1}\end{array}$ & $\begin{array}{c}\mathrm{Mg}^{2+} \\
\mathrm{mgL}^{-1}\end{array}$ & $\begin{array}{c}\mathrm{Na}^{+} \\
\mathrm{mgL}^{-1}\end{array}$ & $\begin{array}{c}\mathrm{K}^{+} \\
\mathrm{mgL}^{-1}\end{array}$ \\
\hline 15 & 7.30 & 27 & 3.2 & 173 & 29.99 & 6.0 & 0.39 & $\mathrm{nd}$ & 48.01 & 75.33 & 25.03 & 12.52 \\
\hline 16 & 7.71 & 42 & 5.0 & 255 & 89.97 & 7.0 & 0.10 & 7.00 & 73.75 & 111.78 & 27.54 & 13.33 \\
\hline 17 & 7.62 & 41 & 6.6 & 256 & 44.97 & 7.0 & 0.07 & 5.55 & 86.57 & 51.03 & 27.04 & 13.33 \\
\hline 18 & 7.79 & 68 & 7.5 & 427 & 59.98 & 9.0 & 0.01 & 22.63 & 123.45 & 99.63 & 33.07 & 13.73 \\
\hline 19 & 7.23 & 68 & 4.6 & 432 & 19.99 & 8.0 & 0.19 & 22.67 & 107.41 & 106.92 & 34.57 & 21.83 \\
\hline 20 & 7.26 & 68 & 5.1 & 425 & 34.99 & 8.0 & 0.01 & 18.21 & 149.01 & 75.33 & 28.54 & 14.54 \\
\hline 21 & 7.48 & 66 & 6.5 & 422 & 54.98 & 10.0 & $\mathrm{nd}$ & 15.51 & 109.02 & 77.76 & 29.55 & 13.73 \\
\hline Max. & 7.79 & 68 & 7.5 & 432 & 89.97 & 10.0 & 0.39 & 22.67 & 149.01 & 111.78 & 34.57 & 21.83 \\
\hline Min. & 7.23 & 27 & 3.2 & 173 & 19.99 & 6.0 & 0.01 & 5.55 & 48.01 & 51.03 & 25.03 & 12.52 \\
\hline Mean & 7.48 & 54.29 & 5.5 & 341.4 & 47.84 & 7.86 & 0.13 & 15.26 & 99.60 & 85.39 & 29.33 & 14.72 \\
\hline SD & 0.23 & 17.19 & 1.46 & 109.6 & 23.24 & 1.35 & 0.14 & 7.49 & 33.32 & 21.62 & 3.39 & 3.19 \\
\hline
\end{tabular}

nd $=$ not detectable

Table 2d. Physicochemical properties of water samples collected from Sadar Upazila of Manikganj district, Bangladesh

\begin{tabular}{|c|c|c|c|c|c|c|c|c|c|c|c|c|}
\hline Sample ID & $\mathrm{pH}$ & $\begin{array}{c}\mathrm{EC} \\
\mu \mathrm{Scm}^{-1}\end{array}$ & $\begin{array}{c}\mathrm{DO} \\
\mathrm{mgL}^{-1}\end{array}$ & $\begin{array}{c}\mathrm{TDS} \\
\mathrm{mgL}^{-1}\end{array}$ & $\begin{array}{c}\mathrm{Cl}^{-} \\
\mathrm{mgL}^{-1}\end{array}$ & $\begin{array}{c}\mathrm{HCO}_{3}^{-} \\
\mathrm{meL}^{-1}\end{array}$ & $\begin{array}{c}\mathrm{PO}_{4}^{3-} \\
\mathrm{mgL}^{-1}\end{array}$ & $\begin{array}{c}\mathrm{SO}_{4}^{2-} \\
\mathrm{mgL}^{-1}\end{array}$ & $\begin{array}{c}\mathrm{Ca}^{2+} \\
\mathrm{mg}^{-1}\end{array}$ & $\begin{array}{c}\mathrm{Mg}^{2+} \\
\mathrm{mg}^{-1}\end{array}$ & $\begin{array}{c}\mathrm{Na}^{+} \\
\mathrm{mgL}^{-1}\end{array}$ & $\begin{array}{c}\mathrm{K}^{+} \\
\mathrm{mgL}^{-1}\end{array}$ \\
\hline 22 & 7.75 & 82 & 4.4 & 529 & 59.98 & 9.0 & 0.23 & 30.57 & 126.65 & 77.76 & 33.57 & 13.33 \\
\hline 23 & 7.33 & 81 & 4.2 & 519 & 94.97 & 7.0 & 1.08 & 33.53 & 149.01 & 106.92 & 33.07 & 13.33 \\
\hline 24 & 7.71 & 29 & 6.5 & 184 & 39.99 & 9.0 & 0.54 & 12.80 & 38.48 & 72.9 & 26.53 & 14.54 \\
\hline 25 & 7.61 & 29 & 6.3 & 186 & 14.96 & 5.0 & 0.80 & 10.44 & 43.29 & 68.04 & 27.04 & 14.54 \\
\hline 26 & 7.32 & 29 & 7.2 & 185 & 39.99 & 8.0 & 1.65 & 10.23 & 49.61 & 82.62 & 26.53 & 14.54 \\
\hline Max. & 7.75 & 82 & 7.2 & 529 & 94.97 & 9.0 & 1.65 & 33.53 & 149.01 & 106.92 & 33.57 & 14.54 \\
\hline Min. & 7.32 & 29 & 4.2 & 184 & 14.96 & 5.0 & 0.23 & 10.23 & 38.48 & 68.04 & 26.53 & 13.33 \\
\hline Mean & 7.54 & 50 & 5.72 & 320.6 & 49.98 & 7.6 & 0.86 & 19.51 & 81.41 & 81.65 & 29.35 & 14.06 \\
\hline SD & 0.21 & 28.76 & 1.34 & 185.7 & 29.79 & 1.67 & 0.54 & 11.54 & 52.26 & 15.14 & 3.64 & 0.66 \\
\hline
\end{tabular}

Table 2e. Physicochemical properties of water samples collected from from Shivalaya Upazila of Manikganj district, Bangladesh

\begin{tabular}{|c|c|c|c|c|c|c|c|c|c|c|c|c|}
\hline Sample ID & $\mathrm{pH}$ & $\begin{array}{c}\text { EC } \\
\mu \mathrm{Scm}^{-1}\end{array}$ & $\begin{array}{c}\mathrm{DO} \\
\mathrm{mgL}^{-1}\end{array}$ & $\begin{array}{l}\text { TDS } \\
\mathrm{mgL}^{-1}\end{array}$ & $\begin{array}{c}\mathrm{Cl}^{-1} \\
\mathrm{mgL}^{-1}\end{array}$ & $\begin{array}{l}\mathrm{HCO}_{3}^{-} \\
\mathrm{meL}^{-1} \\
\end{array}$ & $\begin{array}{l}\mathrm{PO}_{4}{ }^{-2} \\
\mathrm{mgL}^{-1}\end{array}$ & $\begin{array}{l}\mathrm{SO}_{4}{ }^{2-} \\
\mathrm{mgL}^{-1}\end{array}$ & $\begin{array}{c}\mathrm{Ca}^{2+} \\
\mathrm{mgL}^{-1}\end{array}$ & $\begin{array}{l}\mathrm{Mg}^{2+} \\
\mathrm{mgL}^{-1}\end{array}$ & $\begin{array}{c}\mathrm{Na}^{+} \\
\mathrm{mgL}^{-1}\end{array}$ & $\begin{array}{c}\mathrm{K}^{+} \\
\mathrm{mgL}^{-1} \\
\end{array}$ \\
\hline 27 & 7.35 & 29 & 8.0 & 183 & 24.99 & 8.0 & 0.31 & 9.63 & 48.01 & 92.34 & 27.04 & 14.95 \\
\hline 28 & 7.79 & 43 & 5.5 & 256 & 29.99 & 6.0 & 0.31 & nd & 64.13 & 77.76 & 28.54 & 12.11 \\
\hline 29 & 7.47 & 48 & 3.5 & 308 & 44.99 & 8.0 & 0.30 & nd & 73.75 & 109.35 & 29.55 & 13.33 \\
\hline 30 & 7.58 & 54 & 5.4 & 343 & 24.99 & 9.0 & 0.39 & 0.14 & 78.56 & 58.32 & 34.07 & 14.54 \\
\hline Max. & 7.79 & 54 & 8.0 & 343 & 44.99 & 9.0 & 0.39 & 9.63 & 78.56 & 109.35 & 34.07 & 14.95 \\
\hline Min. & 7.35 & 29 & 3.5 & 183 & 24.99 & 6.0 & 0.3 & 0.14 & 48.01 & 58.32 & 27.04 & 12.11 \\
\hline Mean & 7.55 & 43.5 & 5.6 & 272.5 & 31.24 & 7.75 & 0.33 & 4.89 & 66.11 & 84.44 & 29.8 & 13.73 \\
\hline SD & 0.19 & 10.66 & 1.85 & 69.55 & 9.46 & 1.26 & 0.04 & 6.71 & 13.48 & 21.68 & 3.03 & 1.28 \\
\hline
\end{tabular}

nd $=$ not detectable

\section{Major anionic constituents of water}

Major anionic constituents in water samples collected from different Upazila's of Manikganj district are also presented in Tables 2a-e. The anion chemistry indicated that among the 30 water samples, 20 showed the dominance sequence as $\mathrm{HCO}_{3}{ }^{-}>\mathrm{Cl}^{-}>\mathrm{SO}_{4}{ }^{2-}>\mathrm{PO}_{4}{ }^{3-}$ and the rest 10 samples showed the sequence as $\mathrm{HCO}_{3}{ }^{-}>\mathrm{Cl}^{-}>\mathrm{PO}_{4}{ }^{3-}>\mathrm{SO}_{4}{ }^{2-}$. The mean $\mathrm{Cl}^{-}$concentration of water samples collected from Singair, Harirampur, Ghior, Manikgonj sadar and Shivalaya Upazila of Manikganj district were 78.54, $39.98,47.84,49.98$ and $31.24 \mathrm{mgL}^{-1}$, respectively (Tables 2a-e). The acceptable range of $\mathrm{Cl}^{-}$for fish culture and drinking water is from 150 to $600 \mathrm{mgL}^{-1}$ (Chowdhury, 2007; ECR, 1997). According to WHO (2006), acceptable limit of $\mathrm{Cl}^{-}$in drinking water is $250 \mathrm{mgL}^{-1}$. The average concentration of $\mathrm{HCO}_{3}^{-}$in water samples collected from Singair, Harirampur, Ghior, Manikgonj sadar and Shivalaya Upazila of Manikganj district were $7.86,7.00,7.86,7.60$ and $7.75 \mathrm{meL}^{-1}$, respectively (Tables 2a-e). In respect of $\mathrm{HCO}_{3}{ }^{-}$ content, all the samples were found problematic for irrigation which exceeds the recommended limit (1.51 $\mathrm{meL}^{-1}$ ) as reported by Ayers and Westcot (1985). The mean value of $\mathrm{PO}_{4}{ }^{3-}$ were $0.56,0.48,0.13,0.86$ and $0.33 \mathrm{mgL}^{-1}$ in water samples collected from Singair, Harirampur, Ghior, Manikgonj sadar and 
Shivalaya Upazila of Manikganj district, respectively (Tables 2a-e). This anion values were under the permissible limit $\left(2.00 \mathrm{mgL}^{-1}\right)$ for irrigation as reported by Ayers and Westcot (1985). The mean $\mathrm{SO}_{4}{ }^{2-}$ content in water samples collected from Singair, Harirampur, Ghior, Manikgonj sadar and Shivalaya Upazila of Manikganj district were 1.99, 2.39, 15.26, 19.51 and $4.89 \mathrm{mgL}^{-1}$, respectively (Tables 2a-e). The acceptable range of $\mathrm{SO}_{4}{ }^{2-}$ for drinking water is $400 \mathrm{mgL}^{-1}$ as reported by WHO (2006). Maximum permissible limit of $\mathrm{SO}_{4}{ }^{2}$ in irrigation water is $20.00 \mathrm{mgL}^{-1}$ (Ayers and Westcot, 1985). The study results indicated that measured $\mathrm{SO}_{4}{ }^{2-}$ of all water samples were under the acceptable range.

\section{Major cationic constituents of water}

The cation chemistry was dominated by calcium, magnesium, sodium and potassium in the water. The mean concentration of $\mathrm{Ca}^{2+}$ in water samples collected from Singair, Harirampur, Ghior, Manikgonj sadar and Shivalaya Upazila of Manikganj district were $71.91,82.68,99.60,81.41$ and $66.11 \mathrm{mgL}^{-1}$, respectively (Tables 2a-e). Irrigation water containing less than $20 \mathrm{meL}^{-1}\left(801.6 \mathrm{mgL}^{-1}\right)$ of $\mathrm{Ca}^{2+}$ is suitable for irrigating crops (Ayers and Westcot, 1985). So, on the basis of $\mathrm{Ca}^{2+}$ content, all water samples could safely be used for irrigation in the study area. The contribution of $\mathrm{Ca}^{2+}$ content in water was largely dependent on the solubility of $\mathrm{CaCO}_{3}, \mathrm{CaSO}_{4}$ and rarely on $\mathrm{CaCl}_{2}$ (Karanth, 1994). The average concentration of $\mathrm{Mg}^{2+}$ in water samples collected from Singair, Harirampur, Ghior, Manikgonj sadar and Shivalaya Upazila of Manikganj district were 97.24, 120.81, 85.39, 81.65 and $84.44 \mathrm{mgL}^{-1}$, respectively (Tables 2a-e). The acceptable range of $\mathrm{Mg}^{2+}$ for drinking water is $150 \mathrm{mgL}^{-1}(\mathrm{WHO}, 2006)$. According to Ayers and Westcot (1985), irrigation water containing below $121.55 \mathrm{mgL}^{-1} \mathrm{Mg}^{2+}$ is suitable for crops and soils. Considering these limits as standard, maximum samples may be used for drinking, household activities and irrigation. The mean concentration of $\mathrm{Na}^{+}$were 33.14, 30.41, 29.33, 29.35 and $29.8 \mathrm{mgL}^{-1}$ in waters of Singair, Harirampur, Ghior, Manikgonj sadar and Shivalaya Upazila of Manikganj district, respectively. According to Ayers and Westcot (1985), irrigation water containing less than $40 \mathrm{meL}^{-1}\left(919.6 \mathrm{mgL}^{-1}\right) \mathrm{Na}$ is suitable for crops and soils. The average concentration of $\mathrm{K}^{+}$present in the water samples collected from Singair, Harirampur, Ghior, Manikgonj sadar and Shivalaya Upazila of Manikganj district were 16.91, 13.73, 14.72, 14.06 and $13.73 \mathrm{mgL}^{-1}$, respectively (Tables 2a-e). According to Ayers and Westcot (1985), the recommended limit of $\mathrm{K}$ in irrigation water is $2.0 \mathrm{meL}^{-1}\left(78.20 \mathrm{mgL}^{-1}\right)$, and according to this limit all water samples could safely be used for long term irrigation without any harmful affect on soil.

\section{Arsenic concentration in water}

Arsenic concentration in water samples collected from different location of the study area has been represented in Figures 1a-c. Arsenic concentrations in water samples collected from Charigram, Talibpur, Singair, Jamsha, Joy Mantop, Jamirta and Saista villages of Singair upazila in Manikganj district were $1.62,0.53,1.96,0.69,0.29,0.27$ and $0.80 \mathrm{mgL}^{-1}$, respectively. Similarly, arsenic concentrations in water samples collected from Balla, Gala, Chala, Balara, Harukandi, Ramkrishnapur and Boyra villages of Harirampur upazila in Manikganj district were $4.59,0.43,1.49,5.09,2.40,2.13$ and $1.89 \mathrm{mgL}^{-1}$, respectively. On the other hand, arsenic concentrations in water samples collected from Kalta Hat, Nali, Baniajuri, Baliakhora, Ashapur, Singjuri and Baratia villages of Ghior upazila in Manikganj district were 2.26, 2.02, 1.43, 6.69, trace, trace and trace $\mathrm{mgL}^{-1}$, respectively. It is evident from Figure $1 \mathrm{c}$ that arsenic concentration in water samples was the highest $\left(6.69 \mathrm{mgL}^{-1}\right)$ in the Baliakhora village followed by Kalta Hat village of Ghior upazila in Manikganj district. All observed values of arsenic were exceeded Bangladesh standard value $\left(0.05 \mathrm{mgL}^{-1}\right)$ according to ECR (1997) and WHO standard value $\left(0.01 \mathrm{mgL}^{-1}\right)$ (WHO, 2006). These exceeded arsenic values may be due to the hydrological environmental features and dissolution of arsenic-bearing sulfide minerals. On the basis of the obtained results from the present study, it may be concluded that arsenic concentration in these waters are harmful for human health and livestock. The observed arsenic values in waters of Krishnapur, Betila Mitra, Nabagram, Putail and Balirtek villages of Manikganj Sadar upazila and Uthali, Mahadebpur, Ulail and Arua villages of Shivalaya upazila in Manikganj district were negligible, so that people of these 2 Upazila's are out of health risk due to arsenic. 


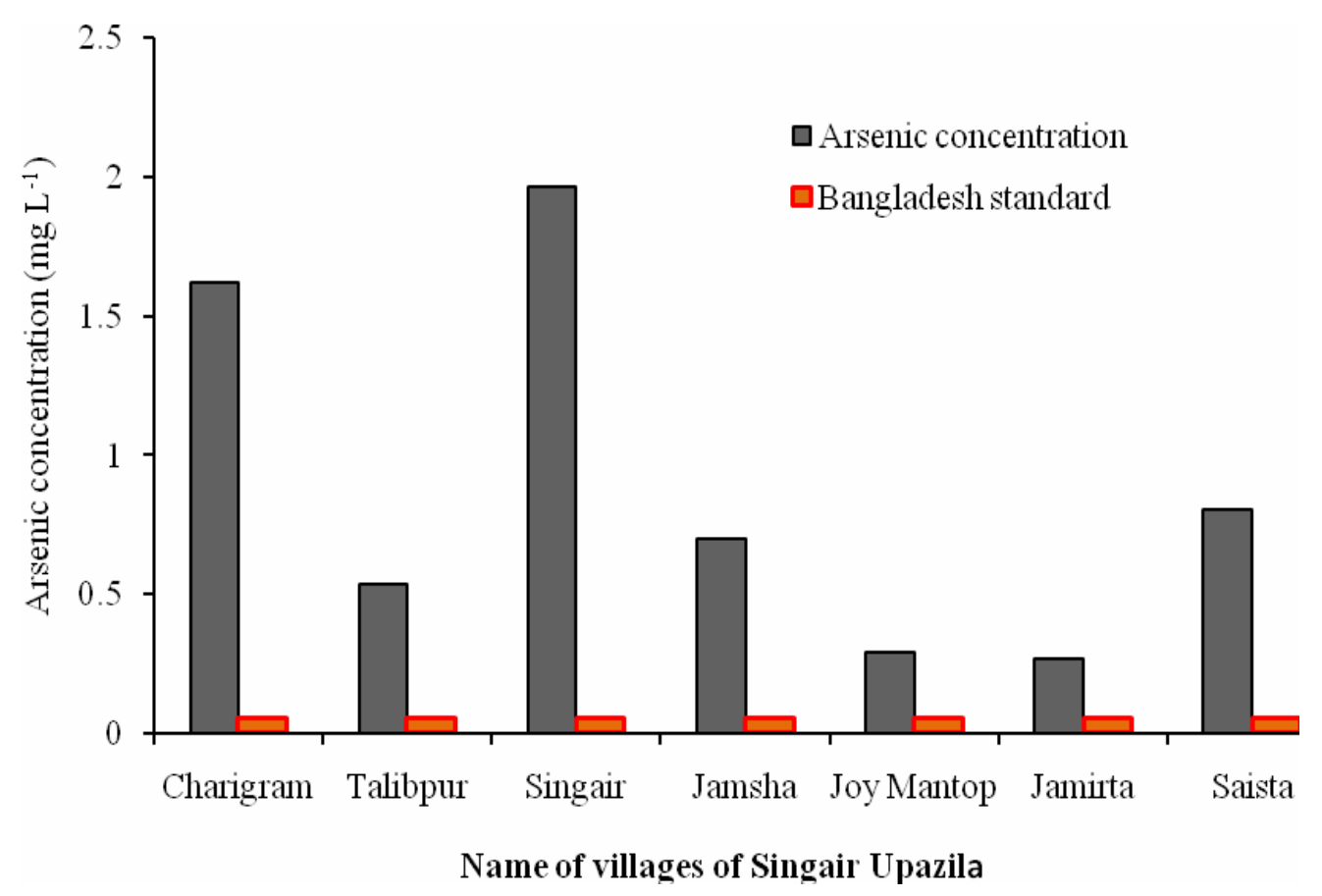

Fig. 1a. Arsenic concentrations in water samples collected from different villages of Singair Upazila of Manikganj district.

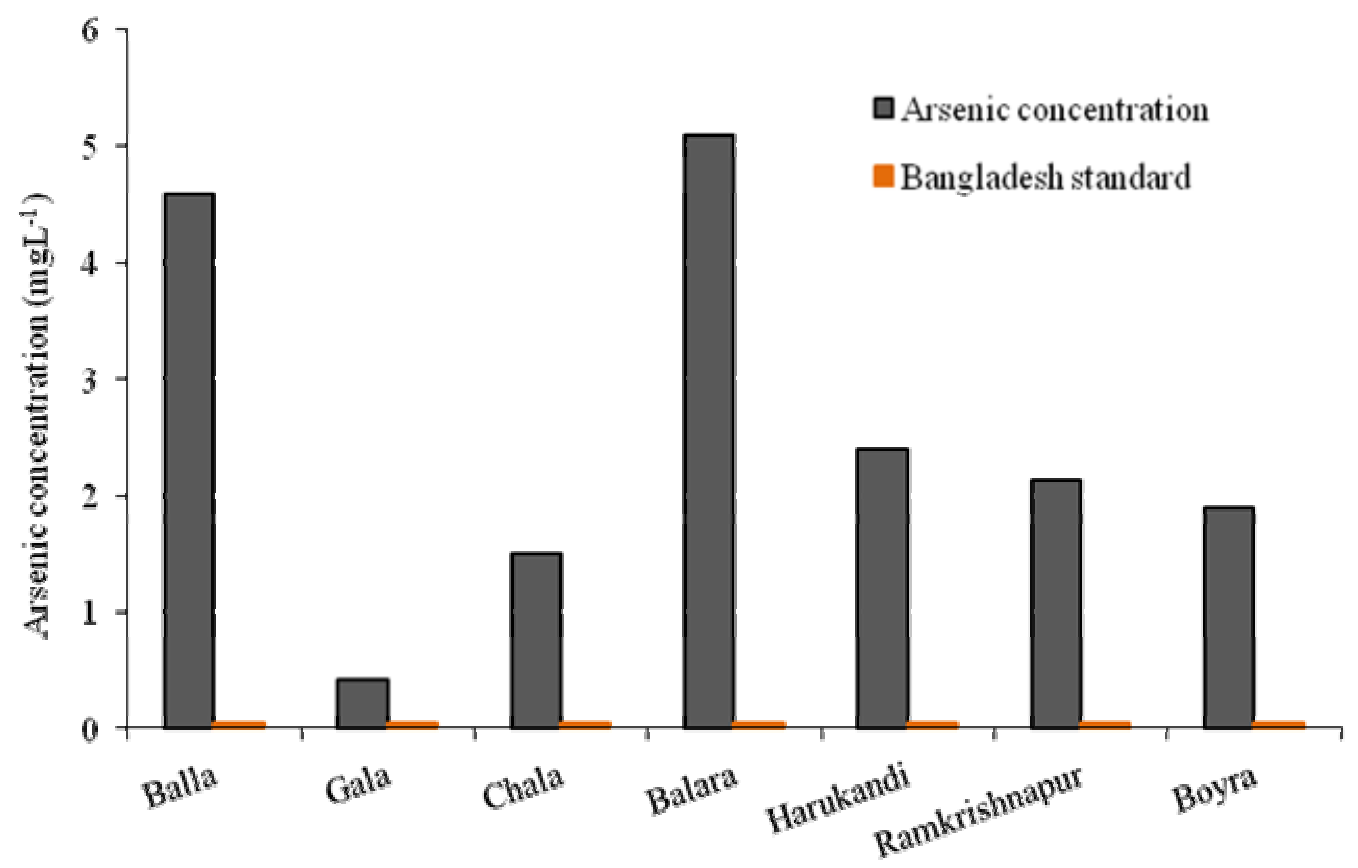

Name of villages of Harirampur Upazila

Fig. 1b. Arsenic concentrations in water samples collected from different villages of Harirampur Upazila of Manikganj district. 


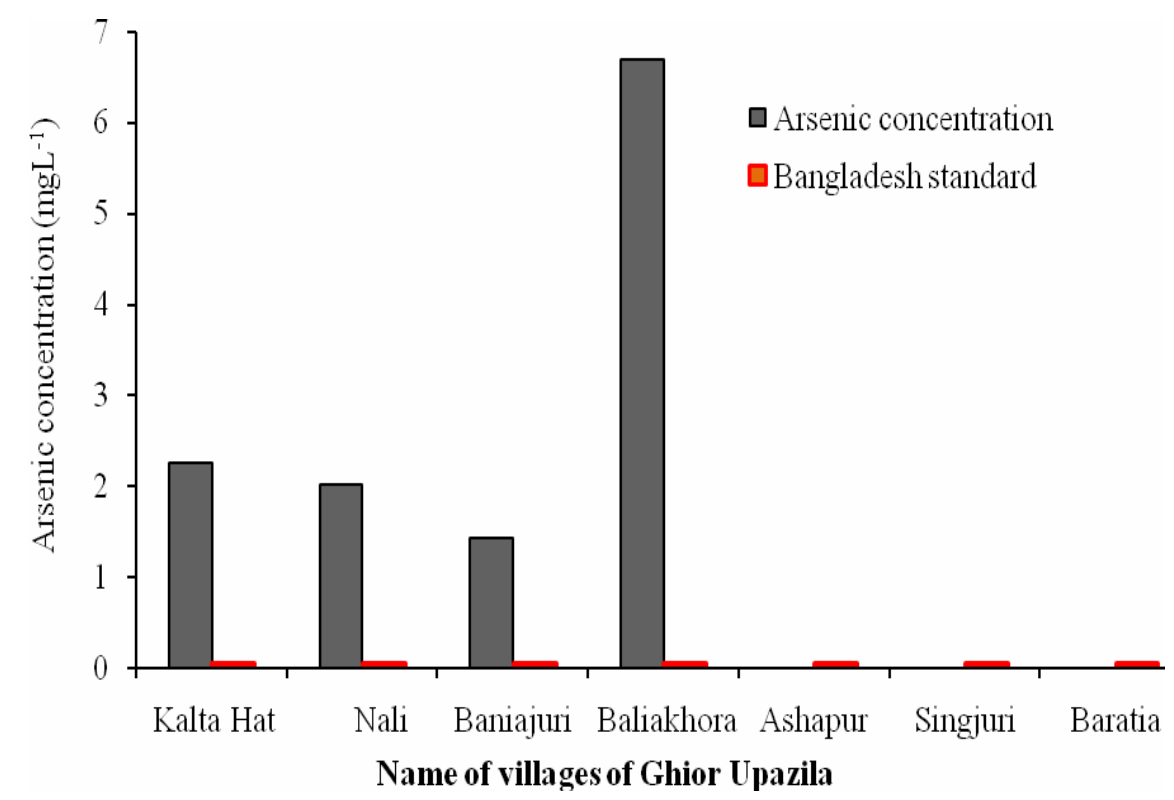

Fig. 1c. Arsenic concentrations in water samples collected from different villages of Ghior Upazila of Manikganj district.

\section{Relationship between arsenic and other ionic constituents}

Correlation matrix for analyzed parameters of water were calculated to see whether some of the parameters were interrelated with each other and the significant results are presented in Figures 2(a \& b). Examination of the matrix also provides clues about the carrier substances and the chemical association of ionic constituents in the study area (Jaquet et al., 1982). Among the relationships between the concentration of As and other physicochemical parameters of water, highly significant positive correlations were found with $\mathrm{SO}_{4}{ }^{2-}\left(\mathrm{r}=712^{\star \star}\right)$ and $\mathrm{Ca}^{2+}\left(\mathrm{r}=581^{*}\right)$ (Figs. 2a-b), suggesting similar sources and/or similar geochemical processes controlling the occurrence of these ions in waters.
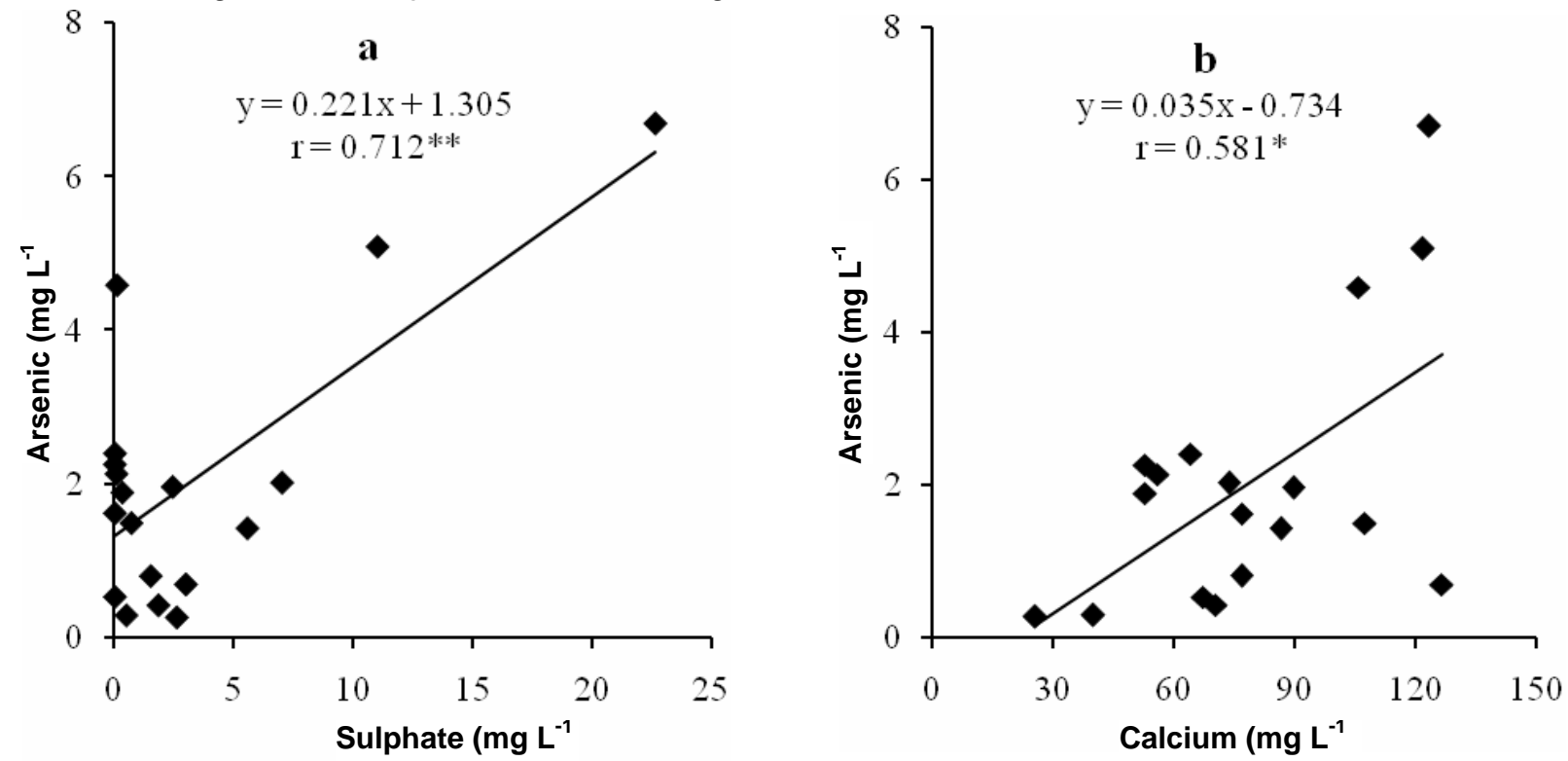

Fig. 2. Relationship between arsenic vs sulphate (a) and arsenic vs calcium (b) obtained for water samples collected from different locations of Manikganj district 


\section{Conclusion}

Concentrations of As in waters collected from Singair, Harirampur and Ghior Upazila of Manikganj district were within the range of 0.27 to $1.96 ; 0.43$ to 5.09 ; trace to $6.69 \mathrm{mg} \mathrm{L}^{-1}$, respectively. But the concentration of As in waters both of Manikganj sadar and Shivalaya Upazila were trace. The present study also revealed that among the 30 water samples studied, 18 samples collected from Singair, Harirampur and Ghior Upazilas of Manikganj district had arsenic, which exceeded Bangladesh standard limit for arsenic concentration $\left(0.05 \mathrm{mgL}^{-1}\right)$. The highest arsenic concentration $\left(6.69 \mathrm{mgL}^{-1}\right)$ in water was found in the Baliakhora village of Ghior upazila in Manikganj district. So, arsenic concentration in these waters are harmful for human health and livestock. On the other hand, the observed arsenic values of water of 3 villages of Ghior Upazila, 5 villages of Manikganj Sadar Upazila and 4 villages of Shivalaya Upazila in Manikganj district were negligible. However, the population exposed to the arsenic contamination should be advised about the arsenic in drinking water, the sources of arsenic-free water and the importance of compliance with treatment programs.

\section{References}

ADB (Asian Development Bank). 1994. Training Manual for Environmental Monitoring. USA: Engineering Science Incorporation, pp. 2-16.

APHA (American Public Health Association). 1995. Standard Methods for the Examination of Water and Waste Water. $19^{\text {th }}$ Edition. Washington DC, pp.1019.

Ayers, R.S. and Westcot, D.W. 1985. Water Quality for Agriculture. FAO Irrigation and Drainage. Paper, $29: 4096$.

Chowdhury, J.A. 2007. Essays on Environment. Botomul Publication, Dhaka Bangladesh. Pp.33-35.

De, A.K. 2005. Water Pollution. Environmental Chemistry. New Age International Publishers, New Delhi, India. pp.189-200.

ECR (The Environment Conservation Rules). 1997. Government of the people's Republic of Bangladesh, Ministry of Environment and Forest.

Farmer, J.G. and Johnson, L.R. 1990. Assessment of occupational exposure to inorganic arsenic based on urinary concentrations and speciation of arsenic. Br. J. Ind. Med., 42:342-348.

Ghosh, A.B., Bijoy, J.C., Hasan, R. and Singh, D. 1983. Soil and Water Testing Method. A Laboratory Manual, Division of Soil Science and Agricultural Chemistry, IARI, New Delhi, India. pp. 221-226.

Imtiaz, M.F., Awal, M.A. and Bepari, A.K. 2009. Arsenic contamination of different food samples from pabna district and its implication for human health. J. Environ. Sci. Natural Resources, 2(2):63-68.

Jaquet, J.M., Davaud, E., Rapin, F. and Vernet, J.P. 1982. Concept and associated statistical methodology in geochemical study of lake sediments. Hydrobiologia, 91, 139 - 146.

Karanth, K.R. 1994. Ground Water Assessment Development and Management. Tata McGraw-Hill Publishing Company Ltd, New Delhi, India. pp.248-250.

Karim, M. 2000. Arsenic in groundwater and health problems in Bangladesh. Water Resources, 34(1):304-310.

Meade, J.W. 1998. Aquaculture Management. CBS Publishers \& Distributors, New Delhi, India. pp. 9.

Page, A.L., Miller, R.H. and Keeney, D.R. 1989. Methods of Soil Analysis. Part-2, $2^{\text {nd }}$ ed., American Soc. Agron. Inc. Pub., Madison, Wisconsin, USA.

Rao, B.K., Panchaksharjah, S., Patil, B.N., Narayana, A. and Kaiker, D.L.S. 1982. Chemical composition of irrigation waters from selected parts of Bijpur district, Karnataka. Mysore J. Agric. Sci., 16(4):426-432.

Sincero, A.P. and Sincero, G.A. 2004. Environmental Engineering: A Design Approach. New Delhi, India: Prentice-Hall of India Private Limited, pp. 120-122.

Singh, D., Chhonkar, P.K. and Pandey, R.N. 1999. Soil, Plant and Water Analysis: A Method Manual. IARI, New Delhi. India, pp. 72-86.

Tandon, H.L.S. 1995. Methods of Analysis of Soils, Plants, Waters and Fertilizers. Fertilizer development and conclusion organization, New Delhi. Pp. 19-23.

WHO (World Health Organization). 2006. Guidelines for Drinking Water Quality. World Health Organization, Geneva, Switzerland. 